\title{
Analysis the Dimension of CSR towards the Relationship between Psychological Contract and Knowledge Sharing
}

\author{
Tiara Puspa1*, Noval Juan Wijaya² \\ ${ }^{1}$ Universitas Trisakti, Faculty of Economics and Business, Jakarta, Indonesia \\ ${ }^{2}$ Universitas Trisakti, Faculty of Economics and Business, Jakarta, Indonesia \\ *Correspondence to: Tiara Puspa, Universitas Trisakti, Faculty of Economics and \\ Business, Jl. Kyai Tapa No. 1, Jakarta Barat 1140, Indonesia. \\ E-mail: tiara.puspa@trisakti.ac.id
}

\begin{abstract}
This research aims to analyze the dimension of corporate social responsibility (consisting of legal and economic) and its relationship to psychological contract, as well as the psychological contract that has relation to knowledge sharing. The object of this sample is employee PT Television Transformation Indonesia (Trans TV) in Jakarta. To test the hypotheses, this study distributed 265 surveys. Among these, 10 surveys were excluded because of incomplete responses. A total of 255 surveys were Analyzed by using the method of Structural Equation Model (SEM). The result shows that legal CSR and Economic CSR has no relation with psychological contract, but the psychological contract has significantly, the positive relation to knowledge sharing. Further research can take another sample from the different media industry.
\end{abstract}

Keywords: corporate social responsibility, legal CSR, economic CSR, knowledge sharing, psychological contract.

Article info: Received 21 April 2018; revised 14 June 2018; accepted 9 July 2018

Recommended citation: Puspa, T., \& Wijaya, N. J. (2018). Analysis the Dimension of CSR towards the Relationship between Psychological Contract and Knowledge Sharing. Indonesian Journal of Sustainability Accounting and Management, 2(2), 107-120.

DOI: 10.28992/ijsam.v2i2.51

\section{Introduction}

The main activity of the company is to conduct business activities. In conducting its activities, each organization must consider in the surrounding environment in order to remain competitive basis in the face of the times. Faced with the dynamics of the external environment, the company is expected to become a flexible company and care about the external environment. In addition to dealing with the impact of globalization, advances in information technology, and the openness of the market, companies must seriously and openly attention to social responsibility disclosure. Corporate Social Responsibility (CSR) is conceptualized as the extent to which an organization would make benefit and contribute to society in a positive way (Madden et al., 2012).

Currently, CSR has been regarded as the company's response to the surrounding environment. According to Habisch \& Wegner (2005) CSR is directed either to the inside or outside company. Inside, the responsibility is directed to shareholders in the form of profitability and growth, in line with this thinking, Luu (2016) that CSR is based on the views of stakeholders in ensuring the sustainability of the company in the long term. To the outside, social responsibility is related to the company's role as a provider of jobs, improving public welfare and competence, as well as preserve the environment for the benefit of future generations. In this 
case, the scope of CSR focus on the company's commitment not only to avoid losses and improve stakeholder interests, but also for the welfare of society (Mohr et al., 2001).

In the environmental and social aspects, CSR is a company's commitment to operating their business legally which is to obey the rules and laws in the attempt, as the economy can run a business for making a profit, and ethically can contribute to the development and improvement of quality of life for company employees, family members of employees, local communities, and society became the company's social environment (Rudito, 2014). At the company's ethical CSR, employees have to be the creation of a psychological contract perspective employees. In this study, researchers tried to take two of the three dimensions of CSR for further investigation, namely legal CSR and economic CSR. According to Luu (2016) legal CSR and economic CSR are limited to a formal contract, which means less to build in sustainability psychological contract employees.

According to Rousseau (2001), psychological contract is the terms and conditions promised by mutual agreement for the exchange between the employee and the superior. Which means, the psychological contract arises when the employee believes that the liabilities of the company to employees will be comparable to the obligations provided by the employee to the company. Psychological contract also alluded to the creation of mutual binding owned by the organization's employees outside the formal contract (Conway \& Briner, 2012). So that adds to the sense of membership (Masterson \& Stamper, 2003). Membership of the organization is felt through the psychological contract cultivates trust in employees (Masterson \& Stamper, 2003), because the psychological contract is an individual's belief in the exchange between individuals and organizations in which the trust itself was created by the organization. This thought is in the line with Guest (2004) that psychological contract employees cultivate the sense of justice in the form of the creation of the atmosphere of exchange and sharing between the individual with other individuals. In addition Puspa (2015) found that a psychological contract encourages a person's thinking process to determine the form of a decision to behave towards his organization. For the examples sharing the knowledge between individuals within an organization.

The creation knowledge sharing is constituted by members of the organization who has more knowledge. In a resource-based view, companies regard knowledge as the resources of the most strategically important, besides knowledge is a valuable resource for modern organizations to survive in the world of a knowledge-based economy as it is today. In order to increase knowledge individually, corporate management should facilitate knowledge sharing to increase the knowledge of new employees (Cabrera \& Cabrera, 2005) and Leonardi (2014) stated knowledge sharing between members of any group allows them to develop and utilize the knowledge based on resources. One way of sharing knowledge between employees and mutual aid in completing a task that will be created by the transfer of knowledge.

In the process of transfer knowledge, knowledge sharing is not only for just exchanging knowledge, but also can help each other solve their respective duties. This opinion is in line with Ibrahim \& Heng (2015) who argued that knowledge sharing is composed of the conversations between members of the organization that allows employees to receive knowledge possessed by other members and can help each other. When this relationship is achieved with both the knowledge sharing process will go well without any problems, it can even improve some things such as loyalty, job satisfaction is high and so on (Kianto et al., 2016).

In this study, carried out an analysis of the relationship of each CSR based dimensions, namely: legal CSR, and economic CSR to psychological contract which also has a relationship to knowledge sharing and applied to the employees of PT Television Transformation Indonesia in Jakarta.

This research was conducted on Trans TV. Trans TV is a company engaged in the broadcasting industry. Employees working in this industry are required to obtain and disseminate information quickly. These demands require knowledge sharing. The phenomenon of the high turnover rate in employees in this company makes 
knowledge sharing an important thing, If the process of knowledge sharing is not done quickly then Trans TV cannot serve the needs of television viewers who always need up to date information.

Knowledge sharing requires a psychological contract, a contract that connects employees and their organizations. Without a psychological contract, one employee is reluctant to provide knowledge sharing to other employees.

The main purpose of this study was to investigate the role of corporate social responsibility, psychological contracts to share knowledge with employees on Trans TV. Research on the role of corporate social responsibility and psychological contracts as an independent variable for knowledge sharing will be interesting because so far less done. Some research on corporate social responsibility has been found in accounting research, and rarely for research in management such as Asmeri et al. (2017); Anazonwu et al. (2018) in addition, research is also conducted in the context of the Indonesian state, interesting because it can test whether the concept of psychological contracts as a form of social exchange theory in western countries can running for the context of Asian countries like Indonesia.

The main purpose of this research is to investigate the role of psychological contracts to knowledge sharing on employees on Trans TV. Research on the role of psychological contract as an independent variable to knowlege sharing will be interesting because so far less done. In addition, research is also conducted in the context of the Indonesian state, it is interesting because it can test whether the concept of psycholgois contract as a form of social exchange theory in the western countries can run for the context of Asian countries such as Indonesia.

Point of view Post et al. (2002) on CSR is expressed in a pyramid consisting of three levels, namely the economic CSR, legal CSR, and ethical CSR. But in this study were taken two of the three dimensions, legal and economic CSR. Legal CSR or corporate responsibility by law requires that businesses do comply with the law. Law understood as a moral view of society because it conforms to the standards of legal norms is a necessary precondition for the further reason for social responsibility. In this case, the public assumes that legal CSR as a truth that must be met by the company to maintain the company's business license Legal CSR should be interpreted as an expression on observance of the moral view of society in which a company is established and conducting business activities, beyond this, CSR legal limit of employees according to the requirements of formal contracts, while the psychological contract is a reciprocal relationship outside the formal contract (Luu, 2016). When legal CSR focuses only company to run the business in accordance with the principles of law, the company cannot meet the psychological contract employees such as not receiving any of the already promised the company to the employees. Thus, the legal CSR negatively related to the psychological contract. Then economic CSR explained that the company's first responsibility is to be a functioning economic unit and stay in business. Therefore, the company has several shareholders who want a fair reward for his investment, employees want a safe job and are paid fairly.

In response to the above matters, the company's focus on CSR economy only in the interests of building a stakeholder so lacking in psychological contracts of employees who are expectations for appointments outside contracted between the company and its employees. Basically, the economic orientation of CSR leads to expectations of stakeholders who have previously promised the company, when the expectations of stakeholders kept as the company works only for the benefit of shareholders. He fulfilled the promises that have been made by the company although outside formal contract. Thus, CSR economy is negatively related to the psychological contract.

The psychological contract is the social exchange relationships that explain the framework for the organization and the individual ties (Gudergan \& Lings, 2010); (Barnhill et al., 2013), in Social Exchange Theory, explained that there is an exchange activity of two or more persons, whether quantifiable or not, more or less harmful or beneficial (Coyle-Shapiro \& Conway, 2004). In addition, the social exchange theory assumes that 
people relate to others because they expect something that meets their needs, such as the psychological contract that employees of the company.

Employee psychological contract is the conviction expressed by the promise and the agreement between employees and the company (Agarwal \& Bhargava, 2013). Membership of the organization is felt through the psychological contract cultivates trust in employees, because of the trust and voluntary actions can be easily intertwined (Masterson \& Stamper, 2003), but it also builds confidence positive attitude towards sharing knowledge. Sharing knowledge or knowledge sharing not only share knowledge, but rather an attitude in which an employee can help each other complete the task so that employees can better contribute to fellow employees In this case, the fulfillment of the psychological contract can create employee alluded to further contribute, for the fulfillment of the psychological contract has a positive relationship with the loyalty of employees who make more employees contribute to the company (Festing \& Schäfer, 2014), When the psychological contract becomes the focus of the company, all employees promise will be kept and have a positive impact by sharing knowledge, because sharing knowledge is created when employees feel happy with how employees are treated by the organization so that employees are reluctant to share his knowledge.

For companies, knowledge is an important thing to maintain a competitive edge (Chiang et al., 2011). Competitive advantage can occur if the employee has knowledge qualified and also may share all his knowledge with other employees for knowledge sharing activities have an important influence in improving the individual innovation. Knowledge Sharing is defined in accordance with the conceptualization (van den Hooff \& de Ridder, 2004) namely as a process in which individuals exchange knowledge implicit (tacit) and explicit individual to create new knowledge.

According to Luu (2016) legal CSR does not focus on the organization, but to the law of the country of doing business. Therefore, legal CSR focuses only on the responsibility to comply with the legal system. Later in the legal CSR merely restrict all activities of the company in accordance formal contract, while the psychological contract is a reciprocal relationship or expectations of the company's promise to the employee outside the formal contract (Conway \& Briner, 2012). This thinking is in line with previous researchers conducted by Luu (2016) said that the legal CSR works only within a contractual exchange only obey the law and focus on business in the country. In this case, the legal CSR limit of employees according to the requirements of the formal contract. Therefore, when the legal CSR are met by the company negatively related to the psychological contract.

Economic CSR, which functions within the framework of labor economics and focuses only on making a profit, because basically, the main motive of the company is generating profits that are the foundation of the company. The company should have economic value as a prerequisite for the company to continue to live and growing. The studies previously conducted by Luu (2016) that the economic CSR only focused on the exchange of economic framework such as making the stakeholders get what is promised the company because the true role of stakeholders in the company is very important in this case, the company focused on the market and the consumer where employees only contribute to productivity by companies that tend to be less build employee psychological contract fulfillment. The psychological contract itself is individual beliefs would reciprocal obligations that may be obtained from employees, and also included the hope or expectation of both parties that implicitly or explicitly been made (Rousseau, 2000). Therefore, when companies contribute more to the responsibility for economic improvement such as achieving maximum profitability, the CSR economy is negatively related to psychological contract because it does not build psychological contract employees such promises unfulfilled.

Knowledge sharing consists of the conversations between members of the organization that allows employees to receive knowledge held by other members (Ibrahim \& Heng, 2015). Members of the organization in leveraging its knowledge when current employees feel that they deserve to be in that organization (Luu, 
2016). Psychological contract touched a thing that can be felt by each binding between employees with the organization outside the formal employment contract (Conway \& Briner, 2012). So that adds to the sense of membership organization (Masterson \& Stamper, 2003), psychological contract establish an atmosphere of membership by allowing employees to work out their duties with fellow employees (Mason \& Simmons, 2014), thus opening up the inventory of their knowledge to more exit and entry of new knowledge. Membership of the organization is felt through the psychological contract, such promises are kept by the company's employees to cultivate trust in employees, because of the trust and voluntary actions can easily be intertwined (Masterson \& Stamper, 2003), the trust also build a positive attitude towards knowledge sharing, especially with a strong sense of the organization's membership is reflected in the psychological contract (Masterson \& Stamper, 2003).

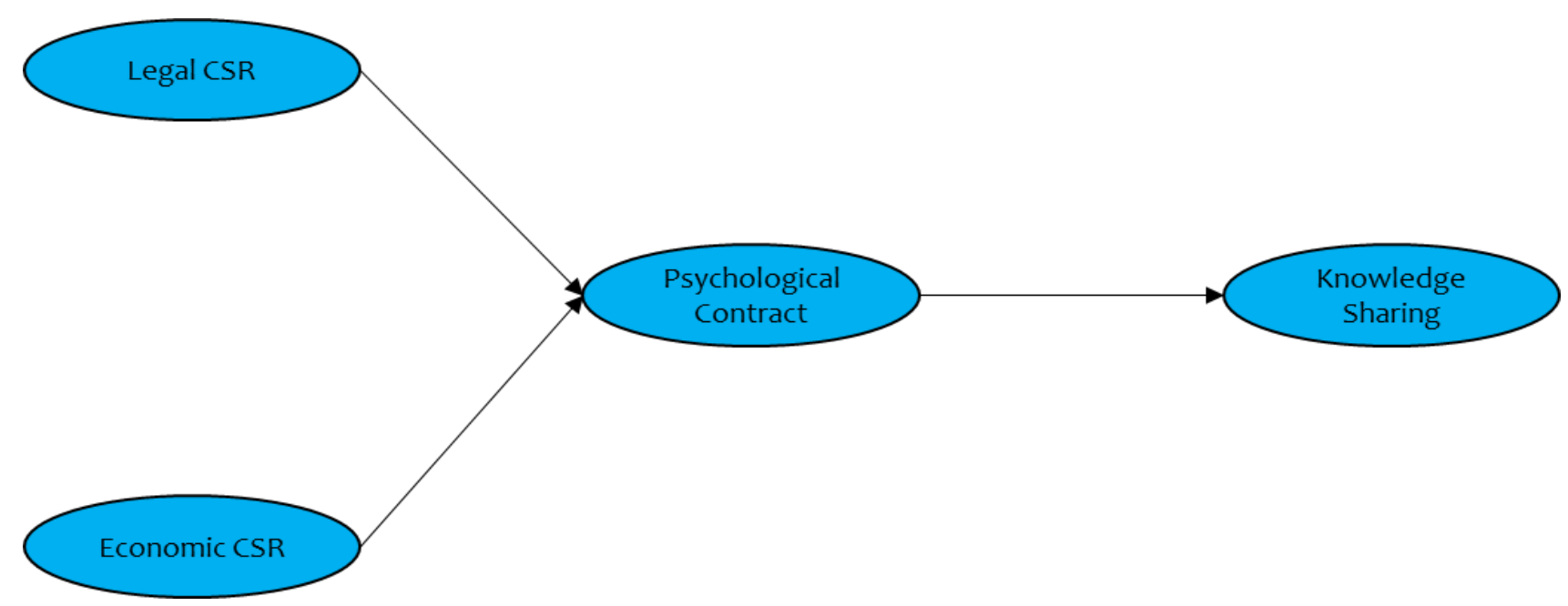

Figure 1 Conceptual Framework

\section{Methods}

In this study, there are two variables: the variable dimensions of CSR (legal CSR and Economic CSR), the independent variable is namely psychological contract, and the dependent variable is knowledge sharing. There are 5 pieces of legal CSR's statement item, CSR economic statement 6 items, 9 items of psychological contract statement, and 14 items of knowledge sharing statement. In this study using 5-point Likert scale (1= strongly disagree and $5=$ strongly agree).

Validity test is done to see how real a test to measure what should be measured (Hartono, 2010). Each variable has a value of factor loading representatives. Factor loading value can be determined based on the number of samples in research (Hair Jr. et al., 2010). In this study, the loading factor used was 0.35 for the total sample of 255 . So if the factor loading $>0.35$ then it can be considered valid.

Reliability test is a term to indicate the extent to which the measurement is relatively consistent if the measurement is repeated twice or more. The reliability of the data in this study were tested using Interitem Consistency Reliability who viewed Cronbach's coefficient alpha as the coefficient of reliability. A Cronbach's alpha reliability coefficient shows how the parts of a set are positively correlated with each other. Basis for a decision for a reliable instrument is if Cronbach's coefficient alpha $(\alpha)$ test $>0.5$, then the statements in the questionnaire feasible to use (reliable). Meanwhile, if the Cronbach's coefficient alpha ( $\alpha$ ) test $<0.5$, then the statements in the questionnaire improperly used (not reliable) (Sekaran \& Bougie, 2013). 
Table 1 Validity Testing Results CSR

\begin{tabular}{cllc}
\hline No. & \multicolumn{1}{c}{ Statement } & $\begin{array}{c}\text { Standardize } \\
\text { Loading factor }\end{array}$ & Decision \\
\hline Legal CSR & 0.728 & Valid \\
\hline 1. $\quad$ Always run the business in accordance with the legal principles & 0.817 & Valid \\
2. $\quad$ Comply with the laws and regulations in all situations & 0.132 & Invalid \\
3. $\quad$ Not having to comply with the law by all means & 0.002 & Valid \\
4. $\quad$ Always adhere to the principles of the latest legal & 0.610 & Valid \\
5. $\quad$ Only allowed to do what is explicitly permitted by law & & \\
\hline Economic CSR & Taking advantage just as the company's attention only & 0.686 & Valid \\
7. $\quad$ Taking profitability as the only measure of effectiveness & 0.735 & Valid \\
8. $\quad$ Always improve economic performance & 0.564 & Valid \\
9. $\quad$ Works only for the benefit of shareholders & 0.629 & Valid \\
10. $\quad$ Doing business only for profit & 0.756 & Valid \\
11. $\quad$ Tied to achieve maximum profitability & 0.703 & Valid \\
\hline
\end{tabular}

Source: processed data (SPSS).

Table 2 Validity Testing Results Psychological Contract

\begin{tabular}{clcc}
\hline No. & \multicolumn{1}{c}{ Statement } & $\begin{array}{c}\text { Standardize } \\
\text { Loading Factor }\end{array}$ & Decision \\
\hline 1. & Almost all the promises made by my superiors for recruitment has been fulfilled & 0.754 & Valid \\
2. $\quad$ I feel that my employer has fulfilled his promise to me & 0.838 & Valid \\
3. $\quad$ So far my boss has done a very good job to fulfill his promises to me & 0.807 & Valid \\
4. I have to accept whatever was promised to me in exchange for my contribution & 0.853 & Valid \\
5. My boss never break a lot of promise to me when I have upheld my side agreement & 0815 & Valid \\
6. I feel a great happiness to my organization & 0.711 & Valid \\
7. I have never been betrayed by my organization & 0.711 & Valid \\
8. I feel that the organization I had never broken a contract between us & 0.747 & Valid \\
9. I was happy with how I was treated by my organization & 0.741 & Valid \\
\hline
\end{tabular}
Source: Data processed (SPSS).

The sampling method of this study is the probability sampling technique that gives an opportunity or equal opportunity for each population to be selected into the sample, the technique used is simple random sampling technique that is taking members of the sample of the population was randomly without regard to strata that exist in the population, PT Television Transformation Indonesia (Trans TV). Trans TV is an 
information service company especially to serve the provision of mass media information on line. The company's concern on the news that is not only up-to-date but still prioritizes ethics and provides benefits to the wider community, makes it one of our considerations to select this company as a sample in this study. It has 1,064 employees divided into 17 department (population), to fare a representative sample of the population, then each subject in the population attempted to have the same opportunities to be sampled. In this study, researchers tried to find the number of samples to look at the total statement of existing questionnaires and multiplied by a scale of 5-10 (Ketchen, 2013).

In this study, researchers deploy questionnaires to employees 265 TRANS TV in Jakarta. But in its implementation, there are four data back to researchers and 6 data that can not be used, so that the total respondents in this study were as many as 255 people.

In this study, the method of data analysis used is Structural Equation Model (SEM). The method used to analyze the relationship or influence between independent variables and the dependent variable in nature to form a path. In the SEM technique, the program used is AMOS.

Table 3 Validity Testing Results Knowledge Sharing

\begin{tabular}{|c|c|c|c|}
\hline No. & Statement & $\begin{array}{c}\text { Standardize } \\
\text { Loading } \\
\text { factor }\end{array}$ & Decision \\
\hline \multicolumn{4}{|c|}{ Donating knowledge } \\
\hline 1. & When I have learned something new, I told my colleagues about it & 0.548 & Valid \\
\hline 2. & When they learn something new, colleagues in my department to tell it to me & 0.632 & Valid \\
\hline 3. & Sharing knowledge with colleagues in my department is considered normal & 0.555 & Valid \\
\hline 4. & $\begin{array}{l}\text { When I have learned something new, I tell colleagues outside my department about } \\
\text { it }\end{array}$ & 0.669 & Valid \\
\hline 5. & When they learn something new, colleagues outside my department to tell it to me & 0.647 & Valid \\
\hline 6. & $\begin{array}{l}\text { Sharing knowledge with colleagues outside my department is considered } \\
\text { commonplace }\end{array}$ & 0.707 & Valid \\
\hline \multicolumn{4}{|c|}{ Collecting Knowledge } \\
\hline 7. & I share the information I have with my colleagues in the office, when they ask & 0.654 & Valid \\
\hline 8. & I share the skills that I have with my colleagues in the office, when they ask & 0.623 & Valid \\
\hline 9. & Colleagues in my office to tell what they know, when I asked them about it & 0.656 & Valid \\
\hline 10. & $\begin{array}{l}\text { Colleagues in my department told me about what their skills, when I asked them } \\
\text { about it }\end{array}$ & 0.693 & Valid \\
\hline 11. & I share the information I have with my colleagues in my department, when they ask & 0.700 & Valid \\
\hline 12. & $\begin{array}{l}\text { I share the skills that I have with my colleagues outside my department, when they } \\
\text { ask }\end{array}$ & 0.662 & Valid \\
\hline 13. & $\begin{array}{l}\text { Colleagues outside my department to tell what they know, when I asked them } \\
\text { about it }\end{array}$ & 0.720 & Valid \\
\hline 14. & Colleagues in my department to say what their skill, when I asked them about it & 0.649 & Valid \\
\hline
\end{tabular}


Table 4 The Reliability Test Results

\begin{tabular}{lccc}
\hline \multicolumn{1}{c}{ Variables } & Item/Statement & Cronbach's Alpha & Decision \\
\hline Legal CSR & 4 & 0.726 & Reliable \\
Economic CSR & 6 & 0.765 & Reliable \\
Psychological Contract & 9 & 0.916 & Reliable \\
Knowledge Sharing & 14 & 0.896 & Reliable \\
\hline
\end{tabular}

Source: Data processed (SPSS).

\section{Results and Discussion}

Looking at the results of descriptive respondents based on sex, it can be seen that in this study the female sex more at 128 or $50.2 \%$ compared to men is 127 , or $49.8 \%$, but the descriptive results of respondents is the female sex cannot be said to be the majority of employees in companies Trans TV because the difference is only a little with the man that is the only difference between one person or the equivalent of $0.2 \%$. This is because that the Trans TV is an industry in the field of creative media can be employed by anyone regardless of gender, both men and women.

Table 5 Profile Characteristics of Respondents Based on Gender, Education, Length Work

\begin{tabular}{|c|c|c|}
\hline Characteristics & Frequency & Percentage (\%) \\
\hline \multicolumn{3}{|l|}{ Gender } \\
\hline Man & 127 & 49.8 \\
\hline Woman & 128 & 50.2 \\
\hline \multicolumn{3}{|l|}{ Last education } \\
\hline Senior High School/Vocational School & 12 & 4.7 \\
\hline Diploma & 26 & 10.2 \\
\hline Bachelor & 217 & 85.1 \\
\hline \multicolumn{3}{|l|}{ Age } \\
\hline $20-30$ & 153 & 60.0 \\
\hline $31-40$ & 70 & 27.5 \\
\hline $41-50$ & 32 & 12.5 \\
\hline \multicolumn{3}{|l|}{ Length of work } \\
\hline $1-3$ & 106 & 41.6 \\
\hline 4-7 & 103 & 40.4 \\
\hline $8-15$ & 38 & 14.9 \\
\hline$>15$ & 8 & 3.1 \\
\hline Total & 255 & 100.0 \\
\hline
\end{tabular}

Source: Data processed (SPSS). 
Based on the results of recent education based on respondents descriptive, it can be seen that the majority of respondents are graduates from bachelor's degree in the amount of 217 respondents, or $85.1 \%$. Meanwhile, another respondent is a diploma which amounted to 26 people, or $10.2 \%$, and a graduate SMA/SMK as many as 12 respondents, equivalent to $4.7 \%$ only. The percentage difference between the last education Senior High School (SHS)/Vocational School, Diploma, and Bachelor's quite striking. This is because employees with Bachelor's background is considered competent and have a broader knowledge in completing the work.In addition, consideration of the company to continuously improve the quality and the quality of its human resources to recruit more graduates in order to increase the qualifying standard recruitment company.

Based on the results of questionnaires have been received from the respondent, it can be seen descriptive respondents age based on namely. Trans TV has employees with an average age of 20-30 as many as 153 or $60 \%$. Meanwhile there are 70 people or $27.5 \%$ of respondents aged $31-40$, and 32 respondents or $12.5 \%$ are aged between 41-50. In this case, the majority of Trans TV employees aged between 20-30, where theage 20-30 years of employee performance fairly productive, because at that age most of the new employees complete their education (fresh graduate), at that age the curiosity and elaborated knowledge is still very large. Therefore, the process of recruitment Trans TV is open to fresh graduates.

Seeing the results of descriptive characteristics of respondents based on length of works, it can be seen that as many as 106 people or $41.6 \%$ of respondents work within a period of 1-3 years. Meanwhile, 103 people or $40.4 \%$ of respondents work in a period of between 4-7 years, and was followed by 38 respondents or $14.9 \%$ were between $8-15$ years old workings, whereas 8 respondents or $3.1 \%$ work in a more than 15 years. This is because PT. Trans TV was officially established in 2001 and has been operating for approximately 17 years, so the majority of employees working longer be in 1-3 years as many as $41.6 \%$ and $40.4 \% 4-7$ years in accordance with the number of employees at a young age and also fresh graduate employees in the company.

The results of the descriptive statistics on CSR legal variables, respondents had an average value of 3.557. It shows that the respondents felt quite agree with Trans TV companies already doing business in accordance with the provisions of applicable law. Meanwhile, the results of descriptive statistics on CSR Economic variables have an average value of 3.457 respondents. This may indicate that respondents felt quite agree that the company Trans TV has been conducting corporate responsibility in economic orientation. Descriptive statistics in the table shows respondents to variable pyschological contract has an average value of 3.757. it illustrates that the respondents quite agree with the psychological contract has been promised to the respondent company, in the sense of respondents agree that these promises have been kept more or less firm. Respondents to variable knowledge sharing by descriptive statistical data in the table above have an average value of 3.947, it shows that the respondents quite agree with the knowledge sharing among colleagues in the office.

Table 6 Descriptive Statistics

\begin{tabular}{|c|c|}
\hline Variables & Total Mean \\
\hline Legal CSR & 3.557 \\
\hline Economic CSR & 3.457 \\
\hline Psychological Contract & 3.757 \\
\hline Knowledge Sharing & 3.947 \\
\hline
\end{tabular}

Source: processed data (SPSS). 


\begin{tabular}{lcc}
\hline \multicolumn{1}{c}{ Hypothesis } & Estimate & p-value \\
\hline Legal CSR negatively related to psychological contract & -0.119 & 0.161 \\
CSR Economic negatively related to psychological contract & 0.032 & 0.694 \\
Psychological contract positively related to knowledge sharing & 0.409 & 0.000 \\
\hline
\end{tabular}
Source: AMOS

The first hypothesis test results showed statistical p-value $0.161>0.05$ with a coefficient of -0.119 . P-value greater than 0.05 indicates that $\mathrm{Ho}$ is accepted and Ha rejected. It can be concluded that the legal CSR does not have a negative relationship with the psychological contract. This means that if according to the company's employees run a CSR legal as possible, it will not be related to the fulfillment of the psychological contract.

The second hypothesis testing results showed statistical $p$-value of $0.032>0.05$ with a coefficient of 0.032. P-value greater than 0.05 indicates that $\mathrm{Ho}$ is accepted and Ha rejected. So the decision is economic CSR hypothesis does not have a negative correlation to the psychological contract. This means that if according to the company's employees carry out economic CSR as possible, it will not be related to the fulfillment of psychological contract, so the third hypothesis does not support previous research.

The third hypothesis testing results showed statistical p-value $0.000<0.05$ with a coefficient of 0.409 . Pvalue less than 0.05 indicates that $\mathrm{Ho}$ is rejected and $\mathrm{Ha}$ accepted, so that the psychological contract has a positive relationship to knowledge sharing. The coefficient of 0.409 indicates the magnitude of the positive inter-relationship between psychological contract to knowledge sharing. It can be concluded that the psychological contract increase knowledge sharing, so that the third hypothesis is supported.

After testing the hypothesis on the second hypothesis, the result p-value $0.694>0.05$. P-value above 0.05 states that accepted ho and ha refused to estimate the value of -0.119 . So on the second hypothesis showed that the legal CSR is not related to the psychological contract directly. That is, if according to the company's employees run a CSR legal as possible, it will not be related to the fulfillment of their psychological contract, so the first hypothesis does not support the hypothesis testing results of previous studies (Luu, 2016).

Differences in results with previous studies (Luu, 2016), due to demographic respondents $85.1 \%$ or 217 people are graduates. Graduates have the knowledgeis extensive enough to have the perspective that the company has been conducting its business in accordance with the provisions of the existing laws of Indonesia. However, in running the business suit or not with the law, they maintained that the psychological contract they still kept, because the factors that make the psychological contract happens is the employee contribution as loyalty and competence, as well as the encouragement of companies such as career opportunities, promotion opportunities, and benefits (Griffin \& Moorhead, 2009), Therefore, the psychological contract and company employees conduct reciprocal relationship mutually beneficial, whereas the CSR legal firm focused solely of regulations that have been made. And it can be concluded that the legal CSR is not negatively related to psychological contract employees.

After testing the hypothesis on the third hypothesis, the result $p$-value $0.694>0.05$. P-value above 0.05 states that accepted ho and ha refused to estimate a value of 0.032 . So on the third hypothesis showed that CSR is not related negative economic psychological contract directly. That is, if according to the company's employees carry out economic CSR as possible, it will not be related to their psychological contract, so that the second hypothesis does not support the hypothesis test results of four previous studies (Luu, 2016).

Differences in results with previous studies (Luu, 2016), caused by the respondent demographic criteria that old workings is between 4-7 years as many as $40.4 \%$ or 103 respondents, so they have a long experience in the company of Trans TV, in which case they assume that when companies bear the responsibility in the 
economy such as taking profits as the focus of the company that has no relationship to the occurrence of psychological contract, whereby they assume that the psychological contract still kept company for psychological contract is the concept of exchange relations employee with the company in terms of employment, while economi CSR is a company's relationship with market, consumers, shareholders. Thus, economic CSR has no relationship with the psychological contract.

After testing the hypothesis in the first hypothesis, the result $\mathrm{p}$-value $0.000<0.05$. P-value below 0.05 states that ho is rejected and Ha accepted. So on the first hypothesis showed that the psychological contract positively related to knowledge sharing directly. Estimate the value of 0.409 indicates that the psychological relationship to knowledge sharing contract is a positive relationship. Thus, if one agrees with the psychological contract has been fulfilled, the employee will feel happy to be in the organization and creation of knowledge sharing would be so easy. That is, if the higher levels of psychological contract fulfilled, the higher the level of knowledge sharing that will be done by fellow employees. Vice versa, if the company does not fulfill the psychological contract to the employee, then the lower the level of knowledge sharing occurs. Thus, the fourth hypothesis testing results of this study support previous research (Luu, 2016).

\section{Conclusion}

Respondents agreed with the company has been engaged in CSR by law (legal CSR) is to comply with all aspects of the law and the norms that exist in Indonesia. These results have seen the base on average CSR legal descriptive statistics of 3.557. then respondents agree with the company has been carrying out its responsibility in the economy (economic CSR) as bonded to achieve maximum profitability. These results were seen based on average economic descriptive statistics of CSR at 3.457. Besides, the respondents agreed with the company has been keeping the promises outside the contract (psychological contract) employees during this time as the company does not deny all the promise that caused respondents felt never betrayed by his company. These results were seen based on average descriptive statistics for 3.758 psychological contract and respondents also agreed with the sharing of knowledge, or knowledge sharing among employees in the organization both outside and inside department respectively. These results were seen based on average descriptive statistical knowledge sharing at 3.947 .

The first hypothesis testing showed that legal CSR does not have any relationship that will be the creation of the psychological contract between employers and employees. The results of this study suggest that the respondents agree that the company running the legal responsibility and the respondent agreed fulfillment of psychological contract in the company, but the achievement of legal CSR is no connection with the fulfillment of the psychological contract. In the first hypothesis is different from the decision hypothesis conducted by Luu (2016), according to the researchers this is due to differences in perspective demographically respondents who have a perspective that companies doing business in accordance or not with the law, the respondents thought that the psychological contract permanent employees kept.

The second hypothesis testing showed that the economic CSR has no direct negative correlation with the psychological contract. The results of this study suggest that the respondents agree that companies carry out activities to contribute to economic responsibility and the respondent agreed with the fulfillment of the psychological contract in the company, but the achievement of economic CSR has nothing to do with the fulfillment of the psychological contract employees. In the third hypothesis is different from the hypothesis that decisions made by Luu (2016).

The third hypothesis testing showed that the psychological contract directly have a positive relationship with knowledge sharing. These results are seen from the respondents' answers were quite agree with the 
fulfillment of the psychological contract between companies and employees to foster trust in each other so that the relationship of exchange such as knowledge sharing.

In the managerial implications, the need is also a concern in this study, namely, to improve the legal CSR, seen from the results of descriptive statistics that respondents are agreed with the company only allowed to do what is clearly permissible by law, so the researchers suggest managers should still obey the law and norms. To improve the economics of CSR, seen from the results of the descriptive statistics that respondents feel that the company is only working for the interests of shareholders, so the researchers suggest managers to pay more attention to the interests of shareholders as profitable fairest. In this study, found the results of descriptive statistics psychological contract stating that the respondents had received any promised to respondents in return for their contributions, so the researchers suggest the manager to keep all its promises to employees such as salary increases, incentive, bonus, career, and etc., that promise will be kept foster a spirit of employees in the work. Things to consider with a view descriptive statistical knowledge sharing that respondents felt that when employees have learned something new, employees told fellow outside the department about it.

Objects in this study have not been able to represent the number of samples of the population is on the employees of PT Trans TV in Jakarta. This study is limited to 255 people those employees. This study is also limited to four variables CSR (legal and economic), psychological contract, and knowledge sharing. So the researchers can add another CSR dimension namely ethical CSR and then moderating variable that is entrepreneur orientation (Luu, 2016). Then further research is expected to add the respondents in the research sample so that research results can be better and further research is expected to study not only focus research on the company, but can be done at other companies, and further research is expected to use all variables in previous research.

\section{References}

Agarwal, U. A., \& Bhargava, S. (2013). Effects of Psychological Contract Breach on Organizational Outcomes: Moderating Role of Tenure and Educational Levels. Vikalpa: The Journal for Decision Makers, 38(1), 13-26.

Anazonwu, H. O., Egbunike, F. C., \& Gunardi, A. (2018). Corporate Board Diversity and Sustainability Reporting: A Study of Selected Listed Manufacturing Firms in Nigeria. Indonesian Journal of Sustainability Accounting and Management, 2(1), 65-78. https://doi.org/10.28992/ijsam.v2i1.52

Asmeri, R., Alvionita, T., \& Gunardi, A. (2017). CSR Disclosures in the Mining Industry: Empirical Evidence from Listed Mining Firms in Indonesia. Indonesian Journal of Sustainability Accounting and Management, 1(1), 16-22. https://doi.org/10.28992/ijsam.v1i1.23

Barnhill, C. R., Andrew Czekanski, W., \& Turner, B. A. (2013). Psychological Contracts and Student-Athlete Retention. Journal for the Study of Sports and Athletes in Education, 7(1), 20-40. https://doi.org/10.1179/1935739713Z.0000000002

Cabrera, E. F., \& Cabrera, A. (2005). Fostering Knowledge Sharing through People Management Practices. The International Journal of Human Resource Management, 16(5), $720-735$. https://doi.org/10.1080/09585190500083020

Chiang, H., Han, T., \& Chuang, J. (2011). The Relationship between High-Commitment HRM and KnowledgeSharing Behavior and its Mediators. International Journal of Manpower, 32(5/6), 604-622. https://doi.org/10.1108/01437721111158224

Conway, N., \& Briner, R. B. (2012). Fifty Years of Psychological Contract Research: What Do We Know and What are the Main Challenges? In G. P. Hodgkinson \& J. K. Ford (Eds.), International Review of Industrial and Organizational Psychology (pp. 71-130). Chichester: John Wiley and Sons, Ltd. https://doi.org/10.1002/9780470745267.ch3 
Festing, M., \& Schäfer, L. (2014). Generational Challenges to Talent Management: A Framework for Talent Retention Based on the Psychological-Contract Perspective. Journal of World Business, 49(2), 262-271. https://doi.org/10.1016/j.jwb.2013.11.010

Griffin, R. W., \& Moorhead, G. (2009). Organizational Behavior: Managing People and Organizations (9th ed.). South-Western.

Gudergan, S., \& Lings, I. (2010). Service Employee Behaviour: The Role of Compliance and Risk Taking. International Journal of Services Technology and Management, 14(2/3), 208-216. https://doi.org/10.1504/IJSTM.2010.034328

Guest, D. E. (2004). The Psychology of the Employment Relationship: An Analysis Based on the Psychological Contract. Applied Psychology, 53(4), 541-555. https://doi.org/10.1111/j.1464-0597.2004.00187.x

Habisch, A., \& Wegner, M. (2005). Germany: Overcoming the Heritage of Corporatism. In A. Habisch, J. Jonker, M. Wegner, \& R. Schmidpeter (Eds.), Corporate Social Responsibility Across Europe (pp. 111-123). Berlin/Heidelberg: Springer-Verlag. https://doi.org/10.1007/3-540-26960-6_10

Hair Jr., J. F., Black, W. C., Babin, B. J., \& Anderson, R. E. (2010). Multivariate Data Analysis (7th ed.). New Jersey: Prentice Hall.

Hartono, J. (2010). Metodologi Penelitian Bisnis: Salah Kaprah dan Pengalaman-Pengalaman. Yogyakarta: BPFE.

Ibrahim, S., \& Heng, L. H. (2015). The Roles of Learning in Stimulating Knowledge Sharing at SMEs. Procedia Social and Behavioral Sciences, 172, 230-237. https://doi.org/10.1016/j.sbspro.2015.01.359

Ketchen, D. J. (2013). A Primer on Partial Least Squares Structural Equation Modeling. Long Range Planning, 46(1-2), 184-185. https://doi.org/10.1016/j.Irp.2013.01.002

Kianto, A., Vanhala, M., \& Heilmann, P. (2016). The Impact of Knowledge Management on Job Satisfaction. Journal of Knowledge Management, 20(4), 621-636. https://doi.org/10.1108/JKM-10-2015-0398

Leonardi, P. M. (2014). Social Media, Knowledge Sharing, and Innovation: Toward a Theory of Communication Visibility. Information Systems Research, 25(4), 796-816. https://doi.org/10.1287/isre.2014.0536

Luu, T. T. (2016). Psychological Contract and Knowledge Sharing: CSR as an Antecedent and Entrepreneurial Orientation as a Moderator. Corporate Communications: An International Journal, 21(1), 2-19. https://doi.org/10.1108/CCIJ-09-2014-0058

Madden, T. J., Roth, M. S., \& Dillon, W. R. (2012). Global Product Quality and Corporate Social Responsibility Perceptions: A Cross-National Study of Halo Effects. Journal of International Marketing, 20(1), 42-57. https://doi.org/10.1509/jim.11.0016

Mason, C., \& Simmons, J. (2014). Embedding Corporate Social Responsibility in Corporate Governance: A Stakeholder Systems Approach. Journal of Business Ethics, 119(1), 77-86. https://doi.org/10.1007/s10551012-1615-9

Masterson, S. S., \& Stamper, C. L. (2003). Perceived Organizational Membership: An Aggregate Framework Representing the Employee-Organization Relationship. Journal of Organizational Behavior, 24(5), 473490. https://doi.org/10.1002/job.203

Mohr, L. A., Webb, D. J., \& Harris, K. E. (2001). Do Consumers Expect Companies to be Socially Responsible? The Impact of Corporate Social Responsibility on Buying Behavior. Journal of Consumer Affairs, 35(1), 45-72. https://doi.org/10.1111/j.1745-6606.2001.tbo0102.x

Post, J. E., Lawrence, A. T., \& Weber, J. (2002). Business and Society: Corporate Strategy, Public Policy, Ethics (10th ed.). New York: Irwin/McGraw-Hill.

Puspa, T. (2015). Pengingkaran Kontrak Psikologis dan Pengaruhnya terhadap Perilaku Kerja Kontraproduktif. Universitas Gadjah Mada.

Rousseau, D. M. (2000). Psychological Contract Inventory Technical Report. Heinz School of Public Policy and Graduate School of Industrial Administration Carnegie Mellon University.

Rousseau, D. M. (2001). Schema, Promise and Mutuality: The Building Blocks of the Psychological Contract. Journal of Occupational and Organizational Psychology, 74(4), 511-541. https://doi.org/10.1348/096317901167505

Rudito, B. (2014). The Improvement of Community Economy as Impact of Corporate Social Responsibility Program: A Case Study in Pengalengan, Bandung, West Java, Indonesia. Procedia - Social and Behavioral Sciences, 164, 471-476. https://doi.org/10.1016/j.sbspro.2014.11.104 
Sekaran, U., \& Bougie, R. (2013). Research Methods for Business: A Skill-Building Approach. John Wiley \& Sons, Inc.

van den Hooff, B., \& de Ridder, J. A. (2004). Knowledge Sharing in Context: The Influence of Organizational Commitment, Communication Climate and CMC Use on Knowledge Sharing. Journal of Knowledge Management, 8(6), 117-130. https://doi.org/10.1108/13673270410567675 